\title{
An Exploration Of The Impact Of Online Delivery In Prerequisite Courses On CIS Majors' Course Sequence
}

Norman Pence (E-mail: pencen@mscd.edu), Metropolitan State College of Denver Janos Fustos (E-mail: pencen@mscd.edu), Metropolitan State College of Denver Wayne Haga (E-mail: pencen@mscd.edu), Metropolitan State College of Denver Kathryn Marold (E-mail: pencen@mscd.edu), Metropolitan State College of Denver Charles H. Mawhinney (E-mail: pencen@mscd.edu), Metropolitan State College of Denver Abel A. Moreno (E-mail: pencen@mscd.edu), Metropolitan State College of Denver Joseph S. Morrell (E-mail: pencen@mscd.edu), Metropolitan State College of Denver Gerard J. Morris (E-mail: pencen@mscd.edu), Metropolitan State College of Denver

\begin{abstract}
On-line courses have become an important component of the delivery of courses in all areas of education. The validity of online delivery is challenged if Web students perform poorly in subsequent major courses. This paper investigates the level of success, failure, potential, and limitation of on-line delivery in the CIS area at MSCD. The result of this research will provide a framework for developing a methodology for this kind of study, allowing academic institutions to evaluate the success and utility of online courses.
\end{abstract}

\section{Introduction}

Educators at institutions everywhere agree that Web courses are here to stay. During the last decade research and statistical analyses of student grades consistently pointed to equality between classroom and the Web courses. Time and again, no significant differences were found in final grades between Web and classroom delivery of courses. The general consensus was that Web courses were working, and that colleges were justified in forging ahead with plans to put entire curricula online.

The first courses to be put online in Information Systems departments were generally the lower level elective courses and courses which were survey or retention-oriented courses. They were enthusiastically received by students and faculty alike. When higher level courses that concentrated on problem solving and analytical ability were put online, faculty began to notice that students taking subsequent courses who had taken the Web-delivered version of the prerequisite were missing some basic concepts. Perhaps the Web-delivered CIS courses requiring this higher level of problem solving were not as successful as the earlier courses which taught students more basic skills. An average knowledge of instructional design and a crash course in Web page editing with Front Page ${ }^{\circledR}$, or even WebCT ${ }^{\circledR}$ or other course authoring software, was enough to move a survey course or a self-paced course to the Web. The actual content of the course was not within the Web pages of the course, but in textbooks and assigned readings listed on the course Web pages. When faced with putting courses that involve problem solving and higher analytical reasoning on the Web, there was concern that the initial success of the first Internet courses was not being repeated. It was time to re-examine the first successes of Web course deployment, and move to examining online prerequisite courses for an IS major in more depth.

\section{Research question}

The authors of this study were instructors of upper level Information Systems courses at a large $(17,000$ students) urban state college in Denver, Colorado. They had offered sections of CMS 2010 Computer Applications 
for Business on the Web since 1996. This course is required for all School of Business majors, whether they will pursue a major in CIS or not. When students become CIS majors, they are required to take CMS 2110 which is a problem solving and logic course. The department has offered the course, CMS 2110 Problem Solving with Structured Programming on the Web since the Fall of 1999. This entrance course for the CIS major requires CMS 2010 as a prerequisite. The investigation and data analysis of this study stemmed from the authors' observations of student performance in the CMS 2110 course. In the first semesters of students fulfilling the prerequisite for the course by taking the online version, authors noticed numerous egregious errors by students in application of theory on tests, homework, and projects. Errors in work demonstrated student lack of understanding of crucial topics. Could this be attributed to the fact that some of these students had taken the prerequisite course online? Were there other factors that might explain the differences in student progress in the CMS 2110 course? Did it make a significant difference in students' progress if they had taken the prerequisite course online?

Observation and anecdotal notes were not enough evidence to declare a problem with Web courses for prerequisites, but a more robust analysis of the first required major course could indicate the need to examine Web delivery of required major courses. Lack of true understanding of concepts appeared to be a problem, but it was not certain how widespread it was, or whether the mode of delivery was a factor. An exploratory preliminary study was designed.

\section{Literature Review}

While there are a myriad of studies on Internet courses and their success, there is not enough on the more subtle aspects of the success or failure of these courses in relation to preparation for subsequent courses. The authors decided to investigate the differences in ability of Internet and classroom students in the subsequent required course in the CIS major.

A wealth of research has already been done on final grades, design of Web courses and delivery of hybrid courses. Research has reported the advantages and disadvantages of Web courses, for both students and faculty (Presby, 2001; Mawhinney, et al, 1998). The social aspects of online student behavior have been researched by McCloskey, et al (1998). Burgstahler (1997) found that students participate more in class discussions when the course is delivered electronically than they would in a traditional class. Dager (1998) found that online training and Web-based training can have greater value today because the courses can be much more interactive, and the results can be tracked automatically. Student demand for complete degrees and certificates of training was found to be increasing significantly by Nixon (1998). Kroder (1998) reported that 8 out of 10 students who responded to a survey of Web course satisfaction said they would take another Internet-based course even though it took more time than a classroom course. Differences in final grades between Internet students and classroom students have been found not to be statistically significant by numerous researchers (Bowman, et al, 1995; Haga \& Marold, 2002, Marold \& Haga, 2003; Mawhinney, et al, 1998; Schulman \& Sims, 1999). The differences in performance and achievement among Web students and classroom students have also been analyzed. Achievement, as evidenced by testing was found to be higher in the Web students; however, performance on projects and homework submissions was found to be higher in classroom students and lower in Web students (Marold \& Haga, 2002.). The credibility of courses completed online as opposed to the classroom has been analyzed (Moreno, Larsen, \& Marold, 2000). Research on the levels of computer literacy by students taking Web courses showed that most students were at a competent level on the Bodker scale, but not at either extreme on the scale--the novice or proficient level. Web literacy and computer literacy in general did not seem to be a barrier to taking an upper level course online (Marold $\&$ Haga, 2002). The midrange achievers in programming courses taken online were found to be the most affected by the distance environment of a Web course (Marold \& Haga, 2003). The attrition rates and failure rates for online courses, and all distance education courses in general, have always been higher than in the classroom. Terry (2001) found that the attrition rates for online MBA courses not only were higher than in the classroom, but as the courses became more analytical and theoretical, the attrition rates increased.

Widespread research on the success of Web delivered courses at all levels continues. Our examination of the literature revealed that the question of how taking prerequisite courses online rather than in the traditional classroom affected performance in subsequent higher level courses had not been sufficiently investigated.. 


\section{Research Plan}

The CIS Department at MSCD offers some courses, ranging from freshman-level to the senior-level, in both an on-line and traditional classroom version. Over the past five years 129 sections of these courses have been offered online while 726 sections have been offered in a traditional classroom setting. The online offerings therefore represent a significant percentage (15\%) of total offerings for the courses offered using both delivery mechanisms. Consequently it is important that the CIS Department studies how a student's performance in a subsequent course is affected by the mode of delivery used for the prerequisite course. From the research question outlined above, the formal plan could be designed.

The research questions then could be rephrased as follows:

\section{Null Hypothesis}

Students taking a problem solving and programming course after they have taken the prerequisite course via the Internet will perform as well or better than students taking the prerequisite course in a traditional classroom.

\section{Alternate Hypothesis}

Students taking a problem solving and programming course after they have taken the prerequisite course via the Internet will not perform as well as students taking the prerequisite course in a traditional classroom.

Course sequences were determined for the study. This sequence consisted of two courses, CMS 2010 and CMS 2110-each of which had a significant number of both online and classroom sections.

\section{Methodology}

The authors developed a plan to collect data from several semesters of course grades and from individual student records and transcripts on the college-wide student records system. One hundred and twenty-seven students' data were gathered.

The collection of variables chosen to analyze student success is outlined in table on the next page.

Data on GPA and grade and course history was gathered from college records. Descriptive data on the student's majors, gender, time period between prerequisite and CMS 2110 course, and how many times each student had attempted the CMS 2110 course were gathered. When the data were gathered, there were several obstacles to a thorough and accurate data analysis:

- $\quad$ Of the 127 students, only 3 had taken the prerequisite course online in the investigated period..

- $\quad$ There were data missing on mode of delivery for 42 of the 127 samples because many students (25\%) were transfer students and had taken the prerequisite course at another institution.

- $\quad$ A few students took the prerequisite and the following CMS 2110 course concurrently.

- Students who had received waivers or otherwise were able to enroll in CMS 2110 without taking the prerequisite course were omitted from the initial sample.

These obstacles in the data sample, primarily the limited number of students who had taken CMS 2010 online, prevented us from testing our hypothesis. Despite the problems with the sample data, the authors believe that the preliminary investigation and analysis proved to be very valuable in providing a prototype for subsequent more in-depth research that could show a significant difference in student performance dependent upon mode of delivery. 


\begin{tabular}{|c|c|c|}
\hline Variable Name & Variable Description & Comment \\
\hline seq & Record sequence number & \\
\hline id & Student ID & \\
\hline name & Student name & \\
\hline gender & Gender & Based on first name. \\
\hline gendern & Gender (numeric) & $\mathrm{f}=0, \mathrm{~m}=1$ \\
\hline major & Student's major & \\
\hline majorn & Major (numeric) & cis $=1$, others $=0$ \\
\hline delv2010 & Delivery method for 2010 & $\mathrm{c}=$ classroom, $\mathrm{o}=$ online \\
\hline delv201n & Delivery method for 2010 (numeric) & classroom $=1$, online $=0$ \\
\hline when 2010 & Year/semester 2010 last taken & Spring $=01$, summer $=02$, fall $=03$ \\
\hline gpa2010 & GPA just prior to 2010 & \\
\hline rep2010 & No. times 2010 attempted & \\
\hline $\operatorname{grd} 2010$ & Grade in 2010 [last attempt] & \\
\hline $\operatorname{grd} 201 \mathrm{n} 1$ & Grade in 2010 [last attempt](numeric) & $\mathrm{A}=4, \mathrm{~B}=3, \mathrm{C}=2, \mathrm{D}=1, \mathrm{~F} / \mathrm{NC}=0, \mathrm{~T}$ disregarded \\
\hline $\operatorname{grd} 201 \mathrm{n} 2$ & Grade in 2010 [last attempt](numeric) & $\mathrm{A}=4, \mathrm{~B}=3, \mathrm{C}=2, \mathrm{D}=1, \mathrm{~F} / \mathrm{NC}=0, \mathrm{~T}=3$ \\
\hline $\operatorname{crn} 2110$ & CRN for 2110 & \\
\hline delv2110 & Delivery method for 2110 & $\mathrm{c}=$ classroom, $\mathrm{o}=$ online \\
\hline delv211n & Delivery method for 2110 (numeric) & classroom $=1$, online $=0$ \\
\hline when 2110 & Year/semester 2110 last taken & Spring $=01$, summer $=02$, fall $=03$ \\
\hline whendiff & when 2110 minus when 2010 & \\
\hline semlag & Semesters between $2010 / 2110$ & $\begin{array}{l}0=\text { concurrent, } 1=\text { previous semester, etc. } \\
\text { two outliers dropped (13 years or more) }\end{array}$ \\
\hline gpa2110 & GPA just prior to 2110 & \\
\hline rep2110 & No. times 2110 attempted & \\
\hline tranhr & No. credits transferred & \\
\hline $\operatorname{grd} 2110$ & Grade in 2010 [last attempt] & \\
\hline $\operatorname{grd} 2110 \mathrm{n}$ & Grade in 2110 [last attempt](numeric) & $\mathrm{A}=4, \mathrm{~B}=3, \mathrm{C}=2, \mathrm{D}=1, \mathrm{~F} / \mathrm{NC} / \mathrm{I}=0$ \\
\hline transfer & Transfer student status & Non-transfer $=0$, transfer $=1$ \\
\hline
\end{tabular}

\section{Analysis}

Of the 127 students, almost two-thirds of them passed the course. This attrition and failure rate is typical of upper level IS courses in an open-admissions institution such as MSCD. Rates for some of upper level analytical courses reach $50 \%$ (Terry, 2001.)

The following are statistically significant $(\mathrm{p}<.05$ 2-tailed) correlations with course grade in CMS 2110 :

1. Females did better than males in CMS 2110.

2. Students with higher GPAs just prior to taking CMS 2010 did better in CMS 2110.

3. Students with higher grades in CMS 2010 did better in CMS 2110 (regardless of whether transfer grades were treated as Cs or disregarded).

4. Students who took the classroom version of CMS 2110 did better than students who took the online version.

5. Students who waited longer after completing CMS 2010 did worse in CMS 2110.

6. Students with higher GPAs just prior to taking CMS 2110 did better in CMS 2110.

7. Students with a higher number of repetitions of CMS 2110 did worse in CMS 2110.

The following variables did not have a statistically significant correlation with course grade in CMS 2110:

1. CIS majors versus non-majors.

2. $\quad$ Mode of delivery of CMS 2010.

3. Number of repetitions of CMS 2010. 
4. Number of transfer credits.

5. Transfer student status.

\section{Discussion}

The study showed that the three students who took the prerequisite course for the required problem solving and programming logic course online performed lower than students who took the prerequisite course in the classroom. This is not an adequate sample with which to draw statistical inference about the population. The authors conclude that the prototype shows promise but that the methodology should be applied to a more robust representative sample.

\section{Conclusions}

It is clear that more research on the success of Web-based courses needs to be done if delivery mode can be termed a significant factor in student progress in a CIS major. This exploratory research project was a necessary first step, but many more semesters of data on these two courses need to be gathered and analyzed. As Web delivery becomes more pervasive and students opt to take online required courses, there will be a much larger sample with fewer obstacles to a thorough data analysis. The authors of this research are currently involved in collecting and analyzing more data for previous and current semesters with the belief that more representative data will show that mode of delivery is a predictor of success in subsequent required courses in CIS majors' sequence. Such research continues as academia commits to improving the delivery of Information Systems curricula.

\section{Summary}

The authors remain committed to Web delivery of department courses. Students who are successful in online courses increase their probability of success in their careers since the Web is pervasive. However, the question of success is highly debatable. It is critical that some method of determining success be developed. The goal of this research is to determine predictors and metrics for success and to use these to measure the success of online delivery. Another goal is to develop a methodology or template so that this research is portable to other areas in other environments.

\section{References}

1. Bowman, B. J., et al. (1995.) "Teaching End User Applications with Computer-based Training. Theory and an Empirical Investigation”, Journal of End User Computing. 7:2. 12-17.

2. Burgstahler, S. (1997.) “Teaching on the Net: what's the Difference?”, T.H.E. Journal. 24:9. 61-64.

3. Dager, N. (1998.) "Little Web Schoolhouse", AV Video Multimedia Producer. 20:12. 15.

4. Haga, W., and K. Marold. (2002.) "Is the Computer the Medium and the Message? A Comparison of Student VB Programming Performance in Three Delivery Modes", The International Business and Economics Research Journal. 1:7. 97-104.

5. Kroder, S. L., J. Suess, and D. Sachs. (1998.) "Lessons in Launching Web-based Graduate Courses", T.H.E. Journal. 25:10. 66-69.

6. Marold, K., and W. Haga. (2002.) "Measuring Online Students' Ability to Apply Programming Theory: Are Web Courses Really Working?", Proceeding of the Thirty-First Western Decision Sciences Institute Meeting. Las Vegas, N.V.

7. Marold, K., and W. Haga. (2003.) "The Emerging Profile of the On-line Learner: Relating Course Performance with Pre-tests, GPA, and other Measures of Achievement", Proceedings of International Resource Management Conference. Philadelphia, PA. May 18-21.

8. Mawhinney, C., et al. (1998.) "Issues in Putting the Business Curriculum Online". Proceedings of the Western Decision Sciences Institute. Puerto Vallarta, MX. April.

9. McCloskey, D., et al. (1998.) "Web-based vs. Traditional Course Deployment: Identifying Differences in User Characteristics and Performance Outcomes". Proceedings of IBSCA Annual Conference. Denver, CO. July, 1998. 
10. Moreno, A., G. Larsen, and K. Marold. (2000.) “The Credibility of Online Learning: A Statistical Analysis of IS Course Delivery at Three Levels", Proceedings of the Western Decision Sciences Institute. Maui, HI.

11. Nixon, M. A., and B. R. Leftwich. (1998.) "Leading the Transition from the Traditional Classroom to a Distance Learning Environment", T.H.E. Journal. 2:6. 54-57.

12. Presby, L. (2001.) "Increasing Productivity in Course Delivery", T.H.E. Journal. 28:7. 52-58.

13. Schulman, A., and R. L. Sims. (1999.) "Learning in an Online Format versus an In-class Format: An Experimental Study", T.H.E. Journal. 26:11. 54-56.

14. Terry, N. (2001.) "Assessing Enrollment and Attrition Rates for the Online MBA", T.H.E. Journal. $28: 7$. 64-68.

Notes 